\title{
The future of ocean governance
}

Bianca Haas ${ }^{1}$, Mary Mackay ${ }^{2,3}$, Camilla Novaglio ${ }^{2,3}$, Liam Fullbrook ${ }^{3,4}$, Michael Murunga $^{3,5}$, Carla Sbrocchi ${ }^{3,6}$, Jan Mcdonald ${ }^{3,7}$, Phillipa C Mccormack ${ }^{3,7}$, Karen Alexander $^{3,5}$, Maree Fudge ${ }^{3,5}$, Lyn Goldsworthy ${ }^{3,5}$, Fabio Boschetti ${ }^{3,8}$, Ian Dutton ${ }^{3,9}$, Leo Dutra $^{3,10}$, Jeffrey Mcgee ${ }^{3,5,7}$, Yannick Rousseau ${ }^{3,5}$, Erica Spain ${ }^{5}$, Robert Stephenson ${ }^{3,11,12,13}$, Joanna Vince ${ }^{3,4}$, Chris Wilcox ${ }^{2,3}$, and Marcus Haward ${ }^{3,5}$

${ }^{1}$ Future Seas

${ }^{2}$ CSIRO, Oceans and Atmosphere

${ }^{3}$ Centre for Marine Socioecology, University of Tasmania

${ }^{4}$ School of Social Sciences, College of Arts, Law and Education, University of Tasmania

${ }^{5}$ Institute for Marine and Antarctic Studies

${ }^{6}$ Faculty of Arts and Social Sciences, University of Technology Sydney

${ }^{7}$ Faculty of Law, University of Tasmania

${ }^{8}$ CSIRO Oceans and Atmosphere, Crawley

${ }^{9}$ Department of Primary Industries

${ }^{10}$ CSIRO Oceans and Atmosphere

${ }^{11}$ Fisheries and Oceans

${ }^{12}$ University of New Brunswick

${ }^{13}$ St. Andrews Biological Station

October 5, 2020

\begin{abstract}
Ocean governance is complex and influenced by multiple drivers and actors with different worldviews and goals. While governance encompasses many elements, in this paper we focus on the processes that operate within and between states, civil society and local communities, and the market, including industry. Specifically, in this paper, we address the question of how to move towards more sustainable ocean governance aligning with the sustainable development goals and the UN Ocean Decade. We address three major risks to oceans that arise from governance-related issues: 1) the impacts of the overexploitation of marine resources; 2) inequitable distribution of access to and benefits from marine ecosystem services, and 3) inadequate or inappropriate adaptation to changing ocean conditions. The SDGs have been used as an underlying framework to develop these risks. We identify five drivers that may determine how ocean governance evolves, namely formal rules and institutions, evidence and knowledge-based decision-making, legitimacy of decision-making institutions, stakeholder engagement and participation, and empowering communities. These drivers were used to define two alternative futures by 2030: (a) 'Business as Usual' - a continuation of current trajectories and (b) 'More Sustainable Future' - optimistic, transformational, but technically achievable. We then identify what actions, as structured processes, can reduce the three major governance-related risks and lead to the More Sustainable Future. These actions relate to the process of co-creation and implementation of improved, comprehensive, and integrated management plans, enhancement of decision-making processes, and better anticipation and consideration of ambiguity and uncertainty.
\end{abstract}

\section{Introduction}


The importance of the oceans cannot be underestimated; thus, effective ocean governance is imperative. The oceans are global common-pool resources managed under national jurisdictions (e.g. territorial waters) and by different sectoral and regional organisations (e.g. Regional Fisheries Organisations, Regional Fisheries Management Organization, International Maritime Organization, the International Seabed Authority). Oceans are governed by numerous actors, formal and informal institutions, and nation-states, for a variety of often conflicting services and uses. Inconsistencies in sectoral approaches, conflicts between actors, jurisdictions with overlapping mandates, and poor communication among governance institutions have undermined the effectiveness of ocean governance (Balgos et al 2015, Stephenson et al 2019). Addressing these challenges is integral to developing effective governance for marine ecosystem sustainability (Alexander and Haward 2019).

While governance encompasses many elements, in this paper we focus on the processes that operate within and between states, civil society and local communities, and the market, including industry (Jentoft and Chuenpagdee 2009; Lemos and Agrawal 2006, Vince and Haward 2019). These processes steer decisionmaking and human interactions with the ocean in response to social, ecological, political or economic change and through, for example, institutional arrangements and legal and policy frameworks. However, governance is more than formal institutions and laws. It encompasses actors (for example states, non-state actors including businesses - and international organisations) and how they influence and implement the rules that mediate human interactions with resources (McGinnis 2011, see also Young 1991).

The complexity of marine socio-ecological systems has often led to ocean governance arrangements in which policies can lack effectiveness (Underdal, 2002; Willock and Lack 2006; Gjerde et al. 2008; Haward and Vince 2008; Blanchard 2017) and coherence (Nilsson et al 2012). International treaties, regional agreements and national policies often comprise complex design, development and implementation, that reflect the desire to move towards specific objectives. To improve oceans governance, the 1992 United Nations Conference on Environment and Development agreement (Chapter 17, Agenda 21) and the 2002 World Summit on Sustainable Development (Vandeweerd et al. 2006) encouraged states to develop and implement integrated ocean and coastal policy approaches. However, ad hoc, disjointed management regimes have resulted in poor compliance among member states (Ban et al. 2014) and poor outcomes, such as overfishing (Hobday et al. 2011) and increasing marine pollution (Vince and Hardesty 2018). This has had negative impacts on the marine ecosystem, markets and society (Rogers at al. 2016).

We use the United Nations Sustainable Development Goals (SDGs) as an underlying framework to identify three major risks for marine ecosystems to frame the discussion of future ocean governance. The SDGs comprise of 17 goals which seek to achieve sustainable development across social, economic, and ecological sectors. These goals are highly interlinked with each other (Singh et al. 2017) and the progress towards these goals will likely impact the ocean. Derived from the SDGs we have summarized three major risks for the ocean where future governance is pivotal for change. These risks are:

1) the impacts of the overexploitation of marine resources e.g. overfishing (SDG12, SDG14, SDG16); 2) inequitable distribution of access to and benefits from marine ecosystem services e.g. technology transfer and gender inequalities (SDG1, SDG8, SDG10, SDG16) (discussed further in Alexander et al, in prep); and 3 ) inadequate or inappropriate adaptation to changing ocean conditions e.g. ocean warming and acidification and sea level rise (SDG1, SDG13, SDG11, SDG16).

Governance has frequently focused on addressing such risks through legal and institutional architecture (Young 2010). There is, however, increasing value in developing an understanding of the impact of interplay and interaction between actors and institutions as well as within these institutions (Beunen et al. 2017; Beunen and Patterson 2016; Scobie 2016). As the climate changes and the oceans face increasing degradation and sustainability challenges, there is a renewed urgency to reform governance structures and systems to address current and emerging problems (Biermann et al. 2010, 2012).

We use these three priority risks for marine ecosystems to frame our discussion on how improved ocean governance may mitigate such risks and offer specific and tangible examples of pathways of change. As such 
we look at addressing these risks through the lens of agency. Agency is defined as the capacity of an actor to make decisions and to act upon them, and thus to influence government and institutions' behaviours (Hall 2010; Bloomfield 2017; Lawrence et al. 2009). Institutions are shaped by the individuals who work within them; addressing agency helps to analyze how institutions are created, how they interact, and how they adapt to changing needs and expectations. By recognising agency as a driver of governance, we can begin to identify interactions between actors that foster or hinder the development of norms and related government systems (Burch et al. 2019) and thus help explain the dynamics of interplay. We use agency as it provides a critical lens that centres on actors within institutions as key to changes ( positive or negative) and thus is a key concept in identifying pathways of change. Agency moves away from a simple focus on state and organisational action.

The aim of this paper is to envision ocean governance for a more sustainable future by 2030 , which is the end of the United Nations Decade of Ocean Science for Sustainable Development, and to propose tangible actions towards such a vision. To address this aim, we identify five drivers (Section 2) shaping ocean governance which will play a key role in the immediate future (Nash et al. 2020). Based on these drivers, we define the narratives of two alternative futures ('business as usual' and an aspirational, more sustainable but technically achievable 2030) (Section 3). These futures are based on the perception and opinions of the authors and we acknowledge that some topics which others might consider as important have not been included. We also identify actions that may facilitate change towards a more sustainable future (Section 4). While not addressed in this paper we acknowledge that the disruptions of 2020, in particular the COVID-19 pandemic, are currently causing major changes to economies and socioecological systems at the global scale. These changes will likely change future trajectories as the COVID-19 pandemic has extensive impacts on for example small-scale and community fisheries (Bennett et al. 2020). Thus, the business as usual scenario we describe is based on evidence from the recent past before the pandemic and assumes a general return to this trajectory in the next few years. We note that current disruptions to the global ocean, environment and society because of COVID-19 may influence the described actions and indeed present a platform for change and an opportunity to 'reset' trajectories in the coming decade (as discussed in Pecl et al. In review, this issue). The more sustainable future presented here is one option for such a shift.

\section{Drivers of change}

We identified five key drivers that influence current ocean governance and can steer the direction of governance within the next decade. These drivers are based on the perceptions and experience of the authors and had been identified in numerous workshops through an established iterative method (see Nash et al. 2020 for more details on this methodology). We acknowledge that the opinion regarding these drivers might differ among different scholars. The first driver is formal rules and institutions (Ostrom 1990). Rules (including norms and regulations) created by formal governance institutions play a role in steering actors' behaviour and the institutional arrangement for the implementation of effective management, which includes compliance and enforcement. The second driver isevidence and knowledge-based decision-making (Cash et al. 2003) as $t$ he sharing of knowledge, brokering between scientific and policy institutions and the acknowledgement of traditional knowledge are important for decision-making processes. The third driver islegitimacy of decisionmaking institutions (Clark et al. 2011). Public's trust is important in decision-making processes and relative outcomes and whether actors judge these processes and outcomes as fair and adequate. The greater the level of legitimacy, the more likely actors will comply with its rules without the need for enforcement actions (Tyler 1990; Franck 1990). The fourth driver isstakeholder engagement and participation (Cash et al. 2003). To facilitate cooperation at all levels of human interaction with the oceans, all relevant stakeholders need to be included in the governance processes. The last driver is empowering communities(Ostrom 1990). Collective actions, as well as social licence for human use of the ocean, benefits the different actors and the various scales at which they operate. Table 1 centres on the three risks in relation to these five key drivers and provides examples of each promoting or undermining ocean governance.

Insert Table 1

\section{Narratives of alternative futures}




\subsection{Business as usual - Managing complexity}

The Business as Usual (BAU) scenario is based on the current status quo predicting that global oceans governance will continue to face highly interconnected and multifaceted problems. The three major risks of the impacts of the overexploitation of marine resources, inequitable distribution of access to and benefits from marine ecosystem services, and inadequate or inappropriate adaptation to changing ocean conditions are partially addressed by some actors, but efforts to address issues related to ocean conservation will not start soon enough and will not be sufficient to place ocean use and exploitation on a sustainable footing (Duarte et al. 2020). Human pressure on marine ecosystems will increase to meet the growing demand for goods and services (Halpern et al. 2020; FAO 2020), and exploitation of marine resources will receive the most attention from government institutions (Sumaila et al. 2019). The distribution of benefits and/or costs will continue to be recognised as an important topic of discussion in national and international fora. However, it will be difficult for actors with different economic interests (e.g. developed and developing states) to agree on solutions that address inequities (Shelton 2008). Adapting to changing ocean conditions will be difficult, due to lags between impacts and policy responses (Blasiak 2020, Slawinski et al. 2017). Knowledge gaps about the oceans such as in species distribution (Menegotto and Rangel, 2018) will persist and these knowledge gaps will undermine prospects for evidence- and knowledge-based decision making (Columbus 2016).

Positive developments will include the widespread adoption of some key international oceans agreements, such as the United Nations Fish Stock Agreement (UNFSA), which is ratified by most countries that harvest straddling and highly migratory fish stocks (United Nations Treaty Collection 2020). The MARPOL Convention - the International Convention for the Prevention of Pollution from Ships - will further reduce vessel-based marine pollution. The draft convention for the conservation and sustainable use of Biodiversity Beyond National Jurisdiction (BBNJ) will enter into force but will lack broad implementation and enforcement capacity as states struggled to reach an agreement (de Santo et al. 2020, Cremers et al. 2020). However, the implementation of the BBNJ agreement will likely be accompanied by an increase in establishing high seas marine protected areas. Besides marine protected areas there will be a growing use of marine spatial planning as a management strategy, which will result in a more coherent ocean management strategies, even though conceptual and practical challenges will remain (Santos et al. 2019).

Formal rules, policies and institutions for oceans management at the national level will continue to be developed or modified iteratively. However, these rules will remain poorly integrated across sectors, resulting in gaps and missed opportunities in addressing the three key risks (Vince 2015). Implementation, compliance, and enforcement will remain patchy, due to lack of resources (Vince et al. 2017) and political will (Nilsson et al. 2019). Governance actors' main priority will be economic growth, promoting, for example, harmful subsidies, which further contributes to overfishing (Sumaila et al 2019). Moreover, the direction of funding towards economy-oriented aspirations may lead to funding cuts for basic research and capacity development or may influence research topics and direction.

Key governance decisions will not make the best use of existing scientific, indigenous, and traditional knowledge (Pentz and Klenk 2017, Weiss et al 2012). With the need for increased evidence-based decision making, new challenges related to data sharing, protection and management will emerge (e.g. Intellectual Property), leaving important information hidden, unavailable or overlooked. Investments in government infrastructure and capacity will remain low, especially in developing nations and small island states, resulting in reliance on outdated research technologies. Despite growing efforts, gaps in knowledge and governance capacity between developed and developing countries will continue, limiting our adaptive and collective responses to ocean governance challenges (Chiarolla 2016).

In a BAU scenario, few parties will acknowledge the need for change, and climate change induced impacts such as redistribution of important species will lead to increased conflicts (Mendenhall et al. 2020). Legitimacy and trust will remain essential for co-governance across scales, but their development will continue to be difficult (Turner et al 2017). Thus, while system-wide legitimacy in some parts of ocean governance may slowly increase at globally significant decision-making meetings, less influential stakeholders will still struggle 
to speak up and be heard. For example, indigenous and traditional stakeholders will increasingly participate in global meetings as a result of international pressure for improved legitimacy and transparency, but their influence on the meetings' outcomes will remain limited (Weiss et al 2013). As a result, the ocean will continue to be governed by a small elite (whose composition varies depending on fluctuating alliances), with members having trade powers and rights of exploitation but different perceptions and understandings of environmental risks and fairness.

Media will play an important role in influencing ocean users and coastal communities (McCombst 2002; Soroka 2003) and will not always make use of the latest scientific evidence (Boykoff 2008). In addition, there will remain a lack of investment in capacity and key infrastructure for communities that are exposed to sea-level rise, oil and gas pollution and other ecological impacts resulting in poor adaptive capacity and high transaction costs for sustainable resource use and collective actions. While some companies will be role models in sustainable resource use, most will participate in "blue-washing" activities (Voyer et al. 2018). For example, deep-seabed mining companies are promoting themselves as sustainable, less invasive and vital to a low-carbon and green-tech based future, despite the potential for vast ecological damage of the industry to seabed ecosystems (Cuvelier et al. 2018; Levin et al. 2016).

\subsection{Sustainable 2030 -Embracing complexity}

Following the approach described in section 2 and by Nash et al. 2020, we explored different future scenarios. Scenario parameters were set by the project teams - see Nash et al. 2020. The scenario drivers and narratives for this paper were developed iteratively through several workshops and discussions by team members identify drivers, constraints and opportunities for the two scenarios elaborated here. Our vision of a More Sustainable Future embraces the complexity of ocean governance and moves towards reducing the three major risks. Unlike non-place management, place management takes into account the distinctive features of an individual place and customize management measures and regulations specific to that place (Young et al. 2007). Adoption and implementation of place-based management and precautionary approaches, together with increased public awareness of ocean overexploitation, will lead to improvements in managing resource use and impacts. A realisation of the need to address social inequity will lead to transformations in cooperation on ocean issues and capacity to adapt to changes in the ocean (Coscieme et al. 2020; Díaz et al. 2019).

In a sustainable 2030 future scenario, new operational rules that complement or reform existing laws will be developed and implemented. Together, these rules will build a more holistic and strategic framework. They will be informed by ambitious objectives shared across players and will be better equipped to address the challenge of fragmented ocean governance. The BBNJ agreement will provide a starting point to address increased pressures from deep-sea resource use. Even though the BBNJ agreement was established on the principle of "not undermining" existing organizations and initiatives, the outcome of the BBNJ negotiations rather strengthens than undermine existing organization (Gjerde et al. 2019). The increasing availability of resources and management capacity will improve compliance and enforcement. Institutional coordination and cooperation between national, sub-national, and local communities will improve sustainable practices and will lead to coordinated efforts to close managerial and regulatory loopholes.

A broader range of organisations and actors will contribute to decisions. Decision-making will be guided by the best available scientific, indigenous, and traditional knowledge. The use of technology will improve monitoring, control and surveillance, and will support more equitable use of ocean resources. Better use of indigenous and traditional knowledge in planning and decision making will improve the legitimacy of ocean governance. Increased transparency will improve the availability of data, will allow scrutiny of decisions and actions, will reduce information asymmetry among actors, and will improve trust amongst important communities and Non-Governmental Organizations (NGO) stakeholders. This will lay the foundation for ongoing negotiations to continue improving and adapting ocean governance over time.

Focused research will advance our understanding of ocean processes. Research will be supported by local communities organised as citizen scientists. Policymakers will use improved research and crowd-sourced data in their strategic planning, emergency preparedness, and adaptive management. Through technological 
advances, local communities will be empowered to participate in monitoring coastal environments against illegal, unreported and unregulated activities, pollution, and sea-level rise. As more local communities and civil society will be engaged in policy and decision-making, their commitment to better oceans management will be strengthened. This will lay the foundations for consensus or acceptable compromises regarding global ocean management goals which will, in time, lead to international commitments.

\section{Pathway to achieve sustainable 2030}

Through the lens of agency, we identified 40 actions across the five drivers to address the three risks highlighted by the Sustainable Development Goals and thus likely leading towards our vision of the sustainable future (Figure 1). We grouped these actions and provide a brief description in the next section (see Appendix 1 for a full list of actions). A clear challenge in moving from a business as usual trajectory is the complex interactions among actors in shaping institutional action or non-action. Enhancing agency of actors such as first nations peoples, whose interests are under-, or non-represented, through engagement and capacity building is a key here.

\subsection{Actions to address the impacts of the overexploitation of marine resources}

Place-based management and planning

Implementing new management plans for the sustainable use of ocean resources requires consideration and coordination of many interacting factors (Jentoft 2000; Leslie et al. 2015; Finkbeiner et al. 2017). It needs input from academia, industry, governments, civil societies, and markets. It demands a renewed focus on implementation, through the creation of place-based management (Leenhardt et al. 2015; Finkbeiner et al. 2017; Mikalsen and Jentoft 2001). Effective place-based management is conditional on the assessment of local conditions. This assessment facilitates the integration of social, cultural and local knowledge, needs and beliefs, and scientific understandings (Actions 1, 2, 30, 32, 33). Examples from the Philippines, Chile, and Mexico showcase such effective place-based management (e.g. Basurto 2005; Gelcich et al. 2007; Gelcich 2010; Kittinger et al. 2013; Pomeroy 2013; Purcell and Pomeroy 2015). Furthermore, resourcing the creation and implementation of comprehensive, integrated management plans has motivated innovative funding arrangements, for example, public-private arrangements such as cost recovery in Australia's New South Wales Rock Lobster Fishery (NSW Government 1994), Canadian fisheries royalty system and aquaculture fees in Norway (Action 5). Auditing of plans and outcomes can be routinely undertaken by governments, environmental NGOs or due to public pressure. In Chile, a Territorial User Rights in Fisheries (TURF) approach has been applied which is a co-management approach which granted exclusive territorial rights to artisanal fishers (Castilla 1994). This approach has been extended by a management policy which fostered the targeted management of specific species within a defined regions, via a management committee, involving different stakeholders such as fisheries, industry and government representatives (Gelcich 2014). The Management Plan policy and its application in TURF environments in Chile have provided a framework for successful access to local and global markets, monitoring, compliance, and auditing (Gelcich 2014) (Actions 3,5,6,11).

Innovative marine business models for marine industries

Market changes can be achieved by altering current business models, for example, through the adoption of more transparent supply chains. This can be done through participation in third-party certification systems, such as the Marine Stewardship Council, and other auditing programs (Actions 25, 26). The application of standards from certification programs to public regulation, as in the forestry industry, can enable industry participants to abide by an additional set of conservation-based measures (Faure et al. 2017). By taking socially and environmentally responsible action, corporations help to achieve a more sustainable future. Annual Impact Reports are published for transparency and demonstrate a clear commitment to human rights, environmental health, and resource sustainability, in addition to returning profits to corporate shareholders (Actions 25, 28, 36). Moreover, shareholders could use their influence to demand change towards more sustainable actions and ensure the publication of those changes to improve transparency (Action 29). Increased focus on sustainability actions within co-management arrangements is also relevant (Actions 37, 38). 


\section{Providing a strong legal basis for protecting marine resources}

Legal frameworks for ocean governance need to adapt to better address emerging governance challenges. This can be achieved by providing incentives for industry to engage with more environmentally friendly practices or by increasing taxes on environmentally harmful behaviour (Action 7). Major issues identified in the Business as Usual scenario were the inconsistency among existing regulations and the lack of coordination when implementing new rules. For more sustainable ocean governance, it is important that legislative and regulatory frameworks are developed in a consistent way and are informed by international and regional legal obligations (Action 9). Cooperation between international (e.g. United Nations Convention for the Law of the Sea - UNCLOS) and regional agreements need to be fostered through the use of mechanisms such as Memoranda of Understanding (MoU) (Action 10). Generally, it is important to incentivize cooperation regarding developing solutions for marine governance issues. Global institutional arrangements need to be established so that participants can directly act through them and support the ambitions of disparate regional and sectoral bodies (Laffoley et al. 2019) (Action 14). Moreover, governance rules need to be clearer and more defined in order to prevent elites from influencing actions (Action 21). In the area of fisheries management, the South Pacific Regional Fisheries Management Organization provides a good example of a more progressive decision-making approach (Schiffman 2013). Increased cooperation is imperative to deal with complexity in ocean governance. To realize this, adequate funding mechanisms for full participation in Conferences of the Parties (CoPs) to global agreements are needed (Laffoley et al. 2019) (Action 12, 16).

\subsection{Actions to address inequitable distribution of access to and benefits from marine ecosystem services}

\section{Fair decision-making process}

The role of procedural and distributional justice in ocean governance cannot be overstated as we strive to build a safe and just operating space for humans and biodiversity (Bennett 2019a; Costanza et al. 1998). Equity, human rights, and social justice are core principles here as envisioned in Agenda 21, RIO +20 and Agenda 2030. Moreover, these principles are important to strengthen an equal distribution of costs and benefits of ecosystem services. It is also important to address the injustice indigenous and traditional people are facing from colonization such as political domination, loss of territory and cultural imposition which are addressed under the 2007 UN Declaration on the Rights of Indigenous People (Moore 2016). For example, the planning and implementation of conservation zones need to be based on more reflexive (Action 3), balanced (Action 29), transparent (Action 23), and inclusive (Action 30) decision-making frameworks that ensure biodiversity and equity goals are considered. These frameworks ensure that communities relying on and benefitting from these and neighbouring zones are engaged and included in the management decisions and processes. Implementing this type of framework will require changes to legislation and policy, as well as new forms of financial incentives. Such changes may be difficult to achieve, especially in low-income countries that face important challenges in the transition towards a fair and just use of natural resources and may require long time frames for full implementation. They are dependent on long-term funding for monitoring, compliance, reporting and surveillance technology (Action 5). However, the application of a human rightsbased approach to ocean governance (Allison 2001; Allison et al. 2012; Zheng 2018) and the movement away from property-rights approaches, may lead to actors taking responsibility for non-inclusivity and overdependence on marketisation and privatisation. Fair ocean citizenry and stewardship may be encouraged. In turn, existing legal and policy frameworks may be improved (Actions 2, 38) and better-suited to achieving sustainable ocean governance (Allison et al. 2012).

\section{Explicit benefit-sharing arrangements}

To achieve equitable and fair ocean governance, the discourse around ocean stewardship, access and use of marine resources, needs to be re-defined. In particular, ocean stewardship needs to address social inequity (Actions 24, 27) (Allison 2001; Bennett 2019b). This approach can offer many opportunities that are supportive of current institutional processes (Action 2), adopt meaningful co-designed governance principles, and have great potential for transformative change (Coscieme et al. 2020; Díaz et al. 2019). For example, 
moving away from the practice of trading-off ecosystem services such as prioritising fish harvesting over environmental damage by fishing gear (Clark et. al 2016; Kaiser et al 2000) can help account for the unequal distribution of costs and benefits across society (Costanza et al. 1998; Daw et al. 2011). As noted in SDG1 (i.e. no poverty): growing social inequality is detrimental to economic growth and may undermine social cohesion and collective action to address governance problems. Thus, mainstreaming benefit-sharing mechanisms and access rights may strengthen stakeholder collaborations (Action 36) and foster the integration of different knowledge types (Actions 18, 19).

\section{Build capacity for those unheard}

Issues in ocean governance can challenge how we cooperate nationally, regionally, and internationally (Action 4) (Campbell and Hanich 2015; Costanza et al. 1998; Díaz et al. 2019). Understanding and achieving equity, alleviating poverty, and enhancing human resilience are required to foster cooperation. This can be done by designing and implementing context-relevant ocean governance policies that consider the marginalised, disenfranchised, and landlocked communities (Bennett 2019a; Coscieme et al. 2020). These communities often lack information, power and influence, a platform, and representation (Actions 29, 30) and are thus less proactive in addressing ocean governance issues (Actions 27, 31, 32, 33, 40). For example, conflict resolution practices can explicitly focus on ensuring representation of all interests, and work hard to provide inclusive practices, and thereby contributing to capacity building. Addressing social inequity will not only facilitate fair-sharing and cross-sectoral cooperation but also transform how humans relate to and interact with the ocean (Campbell and Hanich 2015).

\subsection{Actions to address inadequate or inappropriate adaptation to changing ocean conditions}

\section{Plan and understand and share different approaches}

A pressing action required to face the negative disruptions associated with climate change is to establish what the impacts of change may be (Biesbroek et al. 2010; Mullan et al. 2015; Lesnikowski et al. 2016). In the face of a changing climate, knowledge gaps about oceans and ocean ecosystems are likely to widen. In times of uncertainty (Action 17) monitoring regimes need to be persistent, transparent, and freely available (Action 26). Academia, industry, society (Kelly et al. 2019), politics, and media need to collaborate in collecting and disseminating information and increasing awareness about improving ocean governance. As climate change is already impacting the marine ecosystems, it is important to increase preparedness to respond and recover, either through precautionary recovery plans (Hoeppner and Hughes 2019) or small scale rehabilitation work (Alderman and Hobday 2017). In such contexts, it is also key to consider, assess and monitor the impacts of climate change and different human uses (Halpern et al. 2015; Grech et al. 2016; Mach et al. 2017) (Actions $1,13,35)$. Industries that are susceptible to climate impacts are starting to call on national governments and political parties to acknowledge the effects of the changing climate and move from political contests over evidence to proactive steps to address looming impacts. An example is a recent statement by Australia's largest insurance company calling for effective policies to reduce risk from climate change enhanced natural disasters.

\section{Co-operation on a long timescale}

In times of drastic change, cooperation becomes crucial (Roch and Samuelson 1997; Cardenas et al. 2004). The spectrum of consequences expected from climate change will require legitimate, transparent, and honest cooperation among scientists, industry, society, politicians, and indigenous knowledge holders (Actions 20, 27). Inclusion of indigenous and traditional knowledge and perspectives, for example, allow different viewpoints to be incorporated into decision-making. This also has the potential to improve policy responsiveness as traditional landowners notice some effects of climate change earlier, due to traditional practices and interactions with the oceans (Green and Raygorodetsky 2010). The effects of climate change will not be addressed through short-term policies politics (Slawinski et al. 2017). Whilst flexibility is key to addressing unplanned change, there is a requirement for an imminent strong overarching climate change focused policy and agreements that go beyond typical political timeframes and include whole-of-government responses (Actions 8, 22). Examples of such policy at international levels are the Paris Climate Agreement or the EU Water 
Framework Directive. However, enduring climate change policy on national agendas is lacking (for example, Carbon Pricing in Australia (Crowley 2017)). Governments need to address policy gaps and propose flexible policies that are appealing to increasingly dominant sections of the electorate (Jordan et al. 2015; Burch et al. 2019).

\section{Be ready to respond}

While it is important that future governance regimes adopt decisions based on the precautionary approach (Farbotko and Lazrus 2012; Himes-Cornell and Kasperski 2015; Morzaria-Luna et al., 2014) protecting natural ecosystems also requires governance to be responsive, proactive, and flexible. For example, adaptive management needs to be implemented when addressing the rapid and drastic climate and human-driven change affecting reef areas (Armitage et al. 2009; GBRMPA 2009; Mathews and Turner 2017; Maynard et al. 2010; Townsend et al. 2008; Weeks and Jupiter 2013; Cinner et al. 2019) (Action 3, 38). Last, government and industry need to establish public emergency funds for a rapid response to unexpected and extreme events (Action 39). These funds have already been proposed, for example, for bushfire prevention in Australia (Arriagada et al. 2020) and flood control in the UK (Hannaford and Hall 2019). They complement private emergency funds (e.g. https://climateemergencyfund.org/) and can enable recovery plans (both social and ecosystem), adaptation plans, or new geoengineering approaches (Markusson et al. 2014).

Insert Figure 1

\section{Conclusion}

In this paper, we have argued that ocean governance currently faces three core risks: 1) the impacts of the overexploitation of marine resources, 2) inequitable distribution of access to and benefits from marine ecosystem services; and 3) inadequate or inappropriate adaptation to changing ocean conditions. Various processes will challenge the governance of these risks and agency is key to progressing towards a more sustainable future. This is significant as current knowledge on oceans governance and the role of agency, as we have shown, can provide us with many examples of how we can move towards a more sustainable future. This means we can start to address this now. One way in which to start to address this would be for example to invest in place-based management based on assessments which integrate social, cultural and local knowledge, needs and beliefs and scientific understanding. Furthermore, it is important to increase cooperation among scientists, industry, society, politicians, and indigenous and first nations knowledge holders. These actions might be impacted by disruptions such as the COVID-19 pandemic, however, at this point, it is impossible to describe the extent of the impact. Overall improving governance of the oceans to achieve a more sustainable future - a better future than we can expect under business as usual conditions - is both a challenge and a crucial opportunity for the coming decade.

\section{Acknowledgements}

This paper is part of the 'Future Seas' initiative (www.FutureSeas2030.org), hosted by the Centre for Marine Socioecology at the University of Tasmania. This initiative delivers a series of journal articles addressing key challenges for the UN International Decade of Ocean Science for Sustainable Development 2021-2030. The general concepts and methods applied in many of these papers were developed in large collaborative workshops involving more participants that are listed here as co-authors here, and we are grateful for their collective input. Funding for Future Seas was provided by the Centre for Marine Socioecology, IMAS, MENZIES and the College of Arts, Law and Education, and the College of Science and Engineering at UTAS, and Snowchange from Finland. We acknowledge support from a Research Enhancement Program grant from the DVCR Office at UTAS. We would like to thank Chief Jones and Sutje Hugu for their contribution to this paper. We would also like to thank Carolina Garcia and Danielle Smith for comments on earlier drafts. Thank you to Emily Ogier for providing an internal project review of an earlier draft and the anonymous reviews for improving the manuscript. We acknowledge and pay respect to the traditional owners and custodians of sea country all around the world and recognise their collective wisdom and knowledge of our oceans and coasts. 


\section{References}

Alderman R, Hobday AJ (2017) Developing a climate adaptation strategy for vulnerable seabirds based on prioritisation of intervention options. Deep-Sea Research Part II: Topical Studies in Oceanography, Elsevier Ltd, 140, pp. 290-297.

Alexander KA, Haward M (2019) The human side of marine ecosystem-based management (EBM):'Sectoral interplay'as a challenge to implementing EBM. Mar Policy 101:33-38. doi: 10.1016/j.marpol.2018.12.019

Alexander KA, Fleming A, Dambacher JM, Garcia C, Jansen J, Maxwell KE, Melbourne-Thomas J, Mustonen T, Pecl GT, Shaw J, Syme G, Ogier E (in prep). "Equity of our future oceans: reflections on outcomes and practice." Rev Fish Biol Fisher

Allison EH (2001) Big laws, small catches: global ocean governance and the fisheries crisis. J Int Dev 13: 933-950. doi:10.1002/jid.834

Allison EH, Ratner BD, Åsgård B, Willmann R, Pomeroy R, Kurien J (2012) Rights-based fisheries governance: from fishing rights to human rights. Fish Fish 13:14-29. doi: 10.1111/j.1467-2979.2011.00405.x

Arctic Council (2020) The Arctic Council: A backgrounder. https://arctic-council.org/index.php/en/aboutus. Accessed 26 February 2020

Armitage DR, Plummer R, Berkes F, Arthur RI, Charles AT, Davidson-Hunt IJ, Diduck AP, Doubleday NC, Johnson DS, Marschke M (2009) Adaptive co-management for social-ecological complexity. Front Ecol Environ 7:95-102. doi: 10.1890/070089

Arriagada NB, Bowman DM, Palmer AJ, Johnston FH (2020). Climate Change, Wildfires, Heatwaves and Health Impacts in Australia. In: Akhtar R (ed) Extreme Weather Events and Human Health, Springer, Switzerland, pp 99-116.

Balgos M, Cicin-Sain B, VanderZwaag D (2015) A comparative analysis of ocean policies in fifteen nations and four regions. In: Cicn-Sain B, VanderZwaag D, Balgos, M (ed) Routledge Handbook of National and Regional Ocean Policies. Routledge, USA

Ban NC, Bax NJ, Gjerde KM, Devillers R, Dunn DC, Dunstan PK, Hobday AJ, Maxwell SM, Kaplan DM, Pressey RL, Ardron JA, Game ET, Halpin PN (2014) Systematic Conservation Planning: A Better Recipe for Managing the High Seas for Biodiversity Conservation and Sustainable Use. Conserv Lett 7:41-54. doi: $10.1111 /$ conl.12010

Basurto X (2005) How Locally Designed Access and Use Controls Can Prevent the Tragedy of the Commons in a Mexican Small-Scale Fishing Community. Soc Nat Resour 18:643-659. doi: 10.1080/08941920590959631

Bennett NJ (2019a). Marine Social Science for the Peopled Seas. Coast Manage 47:244-252. doi: 10.1080/08920753.2019.1564958

Bennett NJ (2019b) In Political Seas: Engaging with Political Ecology in the Ocean and Coastal Environment. Coast Manage 47:67-87. doi: 10.1080/08920753.2019.1540905

Bennet NJ, Finkbeiner EM, Ban NC, Belhabib D, Jupiter SD, Kitting JN, Mangubhai S, Scholtens J, Gill D, Christie P (2020) The COVID-19 Pandemic, Small-Scale Fisheries and Coastal Fishing Communities. Coast Manage. doi:10.1080/08920753.2020.1766937

Beunen R, Patterson JJ (2016) Analysing institutional change in environmental governance: exploring the concept of "institutional work". J Environ Plan Manag 62:12-29. doi: 10.1080/09640568.2016.1257423.

Beunen R, Patterson J, Van Assche K (2017) Governing for resilience: the role of institutional work. Curr Opin Environ Sustain 28:10-16. doi:10.1016/j.cosust.2017.04.010.

Biermann F, Pattberg P, Zelli F (2010) Global Climate Governance beyond 2012. Architecture, Agency and Adaptation. Cambridge University Press, Cambridge. 
Biermann F et al. (2012) Transforming governance and institutions for global sustainability: key insights from the Earth System Governance Project. Curr Opin Environ Sustain 4:51-60. doi: $10.1016 /$ j.cosust.2012.01.014.

Biesbroek GR, Swart RJ, Carter TR, Cowan C, Henrichs T, Mela H, Morecroft MD, Rey D (2010) Europe adapts to climate change: comparing national adaptation strategies. Global Environ Chang 20:440-450. doi: 10.1016/j.gloenvcha.2010.03.005

Blanchard C (2017) Fragmentation in high seas fisheries: Preliminary reflections on a global oceans governance approach. Mar Policy 84:327-332. doi: 10.1016/j.marpol.2017.06.017

Blasiak R (2020) Climate change vulnerability and ocean governance. In: Cisneros-Montemayor AM, Cheung WWL, Ota Y (eds) Predicting Future Ocean. Sustainability of Ocean and Human Systems Amidst Global Environmental Change. Elsevier, Netherlands, United Kingdom, United States, pp: 357-262

Bloomfield MJ (2017) Dirty Gold: How Activism Transformed the Jewellery Industry. MIT Press, Cambridge, MA.

Boykoff MT (2008) Media and scientific communication: a case of climate change. Geol Soc Spec Publ 305: 11-18. doi: 10.1144/SP305.3

Burch S, Gupta A, Inoue Cristina Y, Kalfagianni A, Persson A, Atsushi I, Patterson J, Jonathan P, Scobie M, Vervoort J (2019) New directions in earth system governance research. Earth system governance 100006. doi: doi.org/10.1016/j.esg.2019.100006

Campbell B, Hanich Q (2015) Principles and practice for the equitable governance of transboundary natural resources: cross-cutting lessons for marine fisheries management. Maritime Studies 14. doi: 10.1186/s40152015-0028-7

Cardenas JC, Ahn R, Ostrom E (2004) Communication and co-operation in a common-pool resource dilemma: A field experiment. In: Huck S (ed) Advances in Understanding Strategic Behaviour, Palgrave Macmillan, UK, pp 258-286.

Cash DW, Clark WC, Alcock F, Dickson NM, Eckley N, Guston DH, Jager J, Mitchell RB (2003) Knowledge systems for sustainable development. Proc Natl Acad Sci U S A 100:8086-8091. doi: $10.1073 /$ pnas. 1231332100

Castilla JC. 1994. The Chilean small-scale benthic shellfisheries and the institutionalization of new management practices. Ecol Int Bull 21:47-63.

Chiarolla C (2016). The Work of the World Intellectual Property Organization (WIPO) and Its Possible Relevance for Global Ocean Governance. In: Attard DJ, Fitzmaurice M (eds) Comprehensive study on effective and sustainable global ocean governance: UN specialized agencies and global ocean governance. IMO (International Maritime Organization)/IMLI (International Maritime Law Institute) research report to the Nippon Foundation, 2016

Cinner JE, Lau JD, Bauman AG, Feary DA, Januchowski FA, Rojas CA, Barnes ML, Bergseth BJ, Shum $\mathrm{E}$,

Lahari R, Ben J, Graham NAJ (2019) Sixteen years of social and ecological dynamics reveal challenges

and opportunities for adaptive management in sustaining the commons. PNAS USA 116:26474-

26483. doi: $10.1073 /$ pnas. 1914812116

Clark MR, Althaus F, Schlacher TA, Williams A, Bowden DA, Rowden AA (2016) The impacts of deep-sea fisheries on benthic communities: a review. ICSE J Mar Sci 73:i51-i69. doi:10.1093/icesjms/fsv123

Clark WC, Tomich TP, van Noordwijk M, Guston DG, Catacutan D, Dickson NM, McNie E (2011) Boundary Work for Sustainable Development: Natural Resources Management at the Consultative 
Group on International Agriculture Research (CGIAR). Proc Natl Acad Sci U S A 113:4615-4622. doi: 10.1073 pnas.0900231108

Columbus (2016) Deliverable 3.1: Report on knowledge gaps and need in different focus areas. https://www.columbusproject.eu/COLUMBUS\%20Del\%203\%201_v2\%20resubmitted\%2007.04.16.pdf. Accessed 21 July 2020

Coscieme L et al. (2020) Multiple conceptualizations of nature are key to inclusivity and legitimacy in global environmental governance. Environ Sci Policy 104:36-42. doi: 10.1016/j.envsci.2019.10.018

Costanza R et al. (1998) Principles for Sustainable Governance of the Oceans. Science, 281:198-199. doi:10.1126/science.281.5374.198

Cremers K, Wright G, Rochette J, Gjerde K, Harden-Davies H (2020) A preliminary analysis of the draft high seas biodiversity treaty. https://www.iddri.org/sites/default/files/PDF/Publications/Catalogue\%20Iddri/Etude/202001-ST0120high\%20seas.pdf. Accessed 2 March 2020

Crowley K (2017) Up and down with climate politics 2013-2016: the repeal of carbon pricing in Australia. Wiley Interdisciplinary Reviews: Climate Change 8: e458. doi: 10.1002/wcc.458.

Cuvelier D, Gollner S, Jones DOB, Kaiser S, Arbizu PM, Menzel L, Mestre NC, Morato T, et al. (2018) Potential Mitigation and Restoration Actions in Ecosystems Impacted by Seabed Mining. Front Mar Sci 5. doi: $10.3389 /$ fmars.2018.00467

Dauvergne P (2018) The power of environmental norms: marine plastic pollution and the politics of microbeads. Environ Politics 27:579-597. doi: 10.1080/09644016.2018.1449090

Daw T, Brown K, Rosendo S, Pomeroy R (2011) Applying the ecosystem services concept to poverty alleviation: the need to disaggregate human well-being. Environ Conserv 38:370-379. doi: $10.1017 /$ S0376892911000506

de Santo E, Mendenhall E, Nyman E, Tiller R (2020) Stuck in the middle with you (and not much time left): The third intergovernmental conference on biodiversity beyond national jurisdiction. Mar Policy 117:103957. doi: 10.1016/j.marpol.2020.103957

Diaz S, et al. (2019) Pervasive human-driven decline of life on Earth points to the need for transformative change. $S$ cience 366 :eaax3100. doi:10.1126/science.aaw3100

Duarte CM, Agusti S, Barbier E, Britten GL, Castilla JC, Gattuso JP, Fulweiler RW, Hughes TP, Knowlton N, Lovelock CE, Lotze HK, Predragovic M, Poloczanska E, Roberts C, Worm B (2020) Rebuilding marine life. Nature 580:39-51. doi: 10.1038/s41586-020-2146-7

FAO (2020) The State of the World Fisheries and Aquaculture 2020. Sustainability in action. http://www.fao.org/3/ca9229en/CA9229EN.pdf. Accessed 21 July 2020

Farbotko C, Lazrus H (2012) The first climate refugees? Contesting global narratives of climate change in Tuvalu. Glob Environ Change 22:382-390. doi: 10.1016/j.gloenvcha.2011.11.014

Faure M, Mascini P, Liu J (2017) Environmental Governance and Common Pool Resources: A comparison of Fishery and Forestry. Rouledge, London

Finkbeiner EM et al (2017) Reconstructing overfishing: Moving beyond Malthus for effective and equitable solutions. Fish Fish Ghoti Papers: 1-12. doi: 10.1111/faf.12245

First Nations Fisheries Council (2020) PSC First Nations Caucus. https://www.fnfisheriescouncil.ca/initiatives/fisheries-management/pacific-salmon-commission-firstnations-caucus/. Accessed 9 April 2020

Franck TM (1990) The Power of Legitimacy Among Nations. Oxford University Press, Oxford 
GBRMPA (2009) Outlook Report 2009 , Great Barrier Reef Marine Park Authority,Townsville. pp 212.

Gelcich S, Edwards-Jones G, Kaiser MJ (2007) Heterogeneity in fishers' harvesting decisions under amarine territorial user rights policy. Ecol Econ 61:246-254. doi: 10.1016/j.ecolecon.2006.02.017

Gelcich S, Hughes TP, Olsson P, Folke C, Defeo O, Fernandez M, Foale S, Gunderson LH, Rodriguez-Sicket C, Scheffer M, Steneck RS, Castilla JC (2010) Navigating transformations in governance of Chilan marine coastal resources. Proc Natl Acad Sci USA, 107:16794-16799. doi: 10.1073/pnas.1012021107

Gelcich S (2014) Towards polycentric governance of small-scale fisheries: insights from the new 'Management Plans' policy in Chile. Aquat Conserv 24:575-581. doi: 10.1002/aqc.2506

Gjerde KM, Dotinga H, Hart S, Molenaar EJ, Rayfuse R, Warner R (2008) Regulatory and Governance Gaps in the International Regime for the Conservation and Sustainable Use of Marine Biodiversity in Areas Beyond National Jurisdiction. IUCN, Gland, Switzerland

Gjerde KM (2012) Challenges to protecting the marine environment beyond national jurisdiction. Int J Mar Coast Law 27:839-847. doi: 10.1163/15718085-12341255

Gjerde KM, Clark NA, Harden-Davies HR (2019) Building a Platform for the Future: the Relationship of the Expected New Agreement for Marine Biodiversity in Area beyond National Jurisdiction and the UN Convention on the Law of the Sea. Ocean Yearbook Online 33:1:44. doi: 10.1163/9789004395633_002

Grech A, Pressey R, Day J (2016) Coal, cumulative impacts, and the Great Barrier Reef. Conserv lett 9:200-207. doi: $10.1111 /$ conl.12208

Green D, Raygorodetsky G (2010) Indigenous knowledge of a changing climate. Clim Change 100:239-242. doi: $10.1007 / \mathrm{s} 10584-010-9804-y$

Gulbrandsen LH (2009) The emergence and effectiveness of the Marine Stewardship Council. Mar Policy 33:654-660. doi: 10.1016/j.marpol.2009.01.002

Gutierrez NL et al. (2012) Eco-label conveys reliable information on fish stock health to seafood consumers. PloS One 7: e43765-e43765. doi: 10.1371/journal.pone.0043765

Hall P (2010) Chapter 7: historical institutionalism in rationalist and sociological perspective. In: Mahoney J, Thelen K (ed) Explaining Institutional Change: Ambiguity, Agency, and Power. Cambridge University Press, Cambridge.

Halpern BS, Frazier M, Potapenko J, Casey KS, Koenig K, Longo C, Lowndes JS, Rockwood RC, Selig ER, Selkoe KA (2015) Spatial and temporal changes in cumulative human impacts on the world's ocean. Nat Commun 6:7615. doi: 10.1038/ncomms8615

Halpern BS, Frazier M, Afflerback J, Lowndes JS, Micheli F, O'Hara C, Scarborough C, Selkoe KA (2019) Recent pace of change in human impact on the world's ocean. Sci Rep 9:11609. doi: 10.1038/s41598-01947201-9

Hannaford J, Hall J (2019) Flood Risk in the UK: Evidence of Change and Management Responses. In: Kundzewicz ZW (ed) Changes in Flood Risk in Europe.Taylor \& Francis Group, London

Haward M, Vince J (2008) Oceans Governance in the Twenty-first Century: Managing the Blue Planet. Edward Elgar Publishing Ltd., Cheltenham UK and Northampton MA USA,

Himes-Cornell A, Kasperski S (2015) Assessing climate change vulnerability in Alaska's fishing communities. Fish Res 162:1-11. doi: 10.1016/j.fishres.2014.09.010

Hobday A J et al. (2011) Ecological risk assessment for the effects of fishing. Fish Res 108:372-384. doi: 10.1016/j.fishres.2011.01.013. 
Hoeppner JM, Hughes L (2019) Climate readiness of recovery plans for threatened Australian species. Conserv Biol 33:534-542. doi: 10.1111/cobi.13270

IMO (2020) International Convention for the Prevention of Pollution from Ships (MARPOL). http://www.imo.org/en/About/Conventions/ListOfConventions/Pages/International-Convention-forthe-Prevention-of-Pollution-from-Ships-(MARPOL).aspx. Accessed 26 February 2020

IPCC (2020) Special Report on the Ocean and Cryosphere in a Changing Climate. https://www.ipcc.ch/srocc/. Accessed 26 February 2020

Jentoft S (2000) Legitimacy and disappointment in Fisheries management. Mar Policy 24:141-148. doi: 10.1016/S0308-597X(99)00025-1

Jentoft S, Chuenpagdee R (2009) Fisheries and coastal governance as a wicked problem. Mar Policy 33:553560. doi: $10.1016 /$ j.marpol.2008.12.002

Jordan AJ, Huitema D, Hilden M, Van Asselt H, Rayner TJ, Schoenefeld JJ, Tosun J, ForsterJ, Boasson EL (2015) Emergence of polycentric climate governance and its future prospects. Nat Clim Change 5: 977-982. doi:10.1038/NCLIMATE2725

Kaiser MJ, Spence FE, Hart PJB (2000) Fishing-Gear Restrictions and Conservation of Benthic Habitat Complexity. Conserv Biol 14:1512-1525 doi: 10.1046/j.1523-1739.2000.99264.

Kelly R, Fleming A, Pecl GT (2019) Citizen science and social licence: Improving perceptions and connecting marine user groups. Ocean Coast Manag 178:104855. doi: 10.1016/j.ocecoaman.2019.104855

Laffoley D, Baxter JM, Amon DJ, Currie DEJ, Downs CA, Hall-Spencer JM, Harden-Davies H, Page R, Reid CP, Roberts CM, Rogers A, Thiele T, Sheppard CRC, Sumaila RU, Woodall LC (2019) Eight urgent, fundamental and simultaneous steps needed to restore ocean health, and the consequences for humanity and the planet of inaction of delay. Aquat Conserv 30:194-208. doi: 10.1002/aqc.3182

Levin LA, Mengerink K, Gjerde KM, Rowden AA, Van Dover CL, Clark MR, Ramirez-Llodra E, Currie B, et al. (2016) Defining "serious harm" to the marine environment in the context of deep-seabed mining. Mar Policy 74:245-259. doi: 10.1016/j.marpol.2016.09.032

Kittinger JN, Finkbeiner EM, Ban NC, Broad K, Carr MH, Cinner JE, Gelcich S, Cornwell ML, Koehn Z, Basurto X, Fujita R, Caldwell MR, Crowder LB (2013) Emerging frontiers in social-ecological systems research for sustainability of small-scale fisheries. Curr Opin Environ Sustain 5:352-357. doi: $10.1016 /$ j.cosust.2013.06.008

Lawrence T, Suddaby R, Leca B (2009) Institutional Work: Actors and Agency in Institutional Studies of Organizations. Cambridge University Press, Cambridge.

Leenhardt P et al. (2015) Challenges, insights and perspectives associated with using social-ecological science for marine conservation. Ocean Coast Manage 115:49-60. doi: 10.1016/j.ocecoaman.2015.04.018

Lemos MC, Agrawal A (2006) Environmental Governance. Annu Rev Environ Resour 31:297-325. doi: 10.1146/annurev.energy.31.042605.135621

Leslie HM et al. (2015) Operationalizing the social-ecological systems framework to assess sustainability. Proc Natl Acad Sci USA 112:5979-5984. doi: 10.1073/pnas.1414640112

Lesnikowski A, Ford J, Biesbroek R, Berrang-Ford L, Heymann SJ (2016) National-level progress on adaptation. Nat Clim Change 6:261-264. doi: 10.1038/NCLIMATE2863

Lindley J, Techera EJ (2017) Overcoming complexity in illegal, unregulated and unreported fishing to achieve effective regulatory pluralism. Mar Policy 81:71-79. doi: 10.1016/j.marpol.2017.03.010

Mace PM (2001) A new role for MSY in single-species and ecosystem approaches to fisheries stock assessment and management. Fish Fish 2:2-32. 
Mach ME, Wedding LM, Reiter SM, Micheli F, Fujita RM, Martone RG (2017) Assessment and management of cumulative impacts in California's network of marine protected areas. Ocean Coast Manag 137:1-11. doi: 10.1016/j.ocecoaman.2016.11.028

Markusson N, Ginn F, Singh Ghaleigh N, Scott V (2014) In case of emergency press here': framing geoengineering as a response to dangerous climate change. Wiley Interdisciplinary Reviews: Climate Change 5:281-290. doi: $10.1002 /$ wcc. 263

Mathews DL, Turner NJ (2017) Ocean cultures: Northwest Coast ecosystems and indigenous management systems. In: Levin PS, Poe MR (ed) Conservation for the Anthropocene Ocean. Elsevier, pp 169-206.

Maynard J, Marshall P, Johnson J, Harman S (2010) Building resilience into practical conservation: identifying local management responses to global climate change in the southern Great Barrier Reef. Coral Reefs 29:381-391. doi: $0.1007 / \mathrm{s} 00338-010-0603-8$

McCombs M (2002) The agenda-setting role of the mass media in the shaping of public opinion. In: Mass Media Economics 2002 Conference. London School of Economics.

McGinnis MD (2011) Networks of adjacent action situations in polycentric governance. Policy Stud J 39:5178. doi: $10.1111 / \mathrm{j} \cdot 1541-0072.2010 .00396 . \mathrm{x}$

Mikalsen KH, Jentoft S (2001) From user-groups to stakeholders? The public interest in fisheries management. Mar Policy 25:281-292. doi: 10.1016/S0308-597X(01)00015-X

Mendenhall E, Hendrix C, Nyman E, Roberts PM, Hoopes JR, Watson JR, Lam VWY, Sumaila UR (2020) Climate change increases the risk of fisheries conflict. Mar Policy 117:103954. doi:

10.1016/j.marpol.2020.103954

Menegotto A, Rangel TF (2018) Mapping knowledge gaps in marine diversity reveals a latitudinal gradient of missing species richness. Nat Commun 9:4713. doi: 10.1038/s41467-018-07217-7

Moore M (2016) 'Justice and Colonialism'. Philos Compass 11:447-461. doi: 10.1111/phc3.12337

Morzaria-Luna HN, Turk-Boyer P, Moreno-Baez M (2014) Social indicators of vulnerability for fishing communities in the Northern Gulf of California, Mexico: Implications for climate change. Mar Policy 45:182-193. doi: $10.1016 /$ j.marpol.2013.10.013

Mullan M, Kingsmill N, Agrawala S, Matus Kramer A (2015) National adaptation planning: lessons from OECD countries. In: Filho WL (ed) Handbook of Climate Change Adaptation, Springer-Verlag, Berlin, Heidelberg, pp 1165-1182.

Nash KL, Alexander K, Melbourne-Thomas J, Novaglio C, Sbrocchi C, Villanueva C, Pecl GT (in review) Developing Achievable Alternate Futures for Key Challenges during the UN Decade of Ocean Science for Sustainable Development. Rev Fish Biol Fisher

Nilsson JA, Fulton EA, Johnson CR, Haward M (2019) How to Sustain Fisheries: Expert Knowledge from 34 Nations. Water 11:213. doi: 10.3390/w11020213

Nilsson M, Zamparutti T, Petersen JE, Nykvist B, Rudberg P, McGuinn J (2012) Understanding policy coherence: Analytic framework and examples of sector-environmental policy interactions in the EU. Environ Policy Gov 22: 395-423. doi: 10.1002/eet.1589

NSW Government (1994) Fisheries Management Act 1994 No 38.

O'Neil K (2015) Basic Research Often Mocked, Targeted for Budget Cuts Due to Lack Of Public Understanding. American Association for the Advancement of Science. https://www.aaas.org/news/basicresearch-often-mocked-targeted-budget-cuts-due-lack-public-understanding. Accessed 6 August 2020 
Ostrom E (1990) Governing the Commons: the Evolution of Institutions for Collective Action. Cambridge University Press, Cambridge

Pecl, G. T, K. Nash, K. Alexander, J. Melbourne-Thomas, C. Novaglio, R. Trebilco, K. Norris, C. Sbrocchi (in review). " Transforming our oceans for the future we want." Rev Fish Biol Fisher

Pentz B, Klenk N (2017) The 'responsiveness gap' in RFMOs: The critical role of decision-making policies in the fisheries management response to climate change. Ocean Coast Manage 145: 44-51. doi:10.1016/j.ocecoaman.2017.05.007

Phal S, Wyles KJ, Thompson RC (2017) Channeling passion for the ocean towards plastic pollution. Nat Hum Behav 1:697-699. doi: 10.1038/s41562-017-0204-4

Pomeroy RS (2013) Sustainable livelihoods and an ecosystem approach to fisheries management. USAID Project Number: GCP LWA Award \# LAG-A-00-99-00048-00. Jakarta, Indonesia: Coral Triangle Initiative on Coral Reefs, Fisheries, and Food Security (CTI-CFF).

Purcell SW, Pomeroy RS (2015) Driving small-scale fisheries in developing countries. Front Mar Sci 2. doi: 10.3389/fmars.2015.00044

Roch SG, Samuelson CD (1997) Effects of environmental uncertainty and social value orientation in resource dilemmas. Organ Behav Hum Decis Process 70:221-235. doi: 10.1006/obhd.1997.2707

Rogers AD, Sumaila R, Hussain SS, Baulcomb C (2016) The High Seas and Us - Understanding the Value of High-Seas Ecosystems. http://www.oceanunite.org/wp-content/uploads/2016/03/High-Seas-andUs.FINAL_.FINAL_.high_.spreads.pdf. Accessed 21 March 2018

Sakaguchi I (2013) The roles of activist NGOs in the development and transformation of IWC regime: the interaction of norms and power. J Environ Stud Sci 3:194-208. doi: 10.1007/s13412-013-0114-3

Santos CF, Ehler CN, Agardy T, Andrade F, Orbach M, Crowder LB (2019) Chapter 30 - Marine Spatial Planning. In: World Seas: an Environmental Evaluation (sec. ed), pp: 571-592. doi: 10.1016/B978-0-12805052-1.00033-4

Schiffman HS (2013) The South Pacific Regional Fisheries Management Organization (SPRFMO): an improved model of decision-making for fisheries conservation? J Environ Stud Sci 3:209-216. doi: 10.1007/s13412-013-0111-6

Scobie M (2016) Policy coherence in climate governance in Caribbean small island developing states. Environ Sci Policy 58:16-28. doi: 10.1016/j.envsci.2015.12.008.

Shelton D (2008) Equity. In Bodansky D, Brunee J, Hey E (eds) The Oxford Handbook of International Environmental Law, Oxford University Press, Oxford doi:10.1093/oxfordhb/9780199552153.013.0027

Singh GG, Cisneros-Montemayor AM, Swartz W, Cheung W, Guy JA, Kenny TA, McOwen CJ, Asch R, Geffert JL, Wabnitz CCC, Sumaila R, Hanich Q, Ota Y (2017). A rapid assessment of co-benefits and tradeoffs among Sustainable Development Goals. Mar Policy 96:223-231. doi: 10.1016/j.marpol.2017.05.030

Slawinski N, Pinkse J, Busch T, Banerjee SB (2017) The role of short-termism and uncertainty avoidance in organizational inaction on climate change: A multi-level framework. Business \& Society 56:253-282. doi: $10.1177 / 0007650315576136$

Soroka SN (2003) Media, Public Opinion, and Foreign Policy. Harvard Int J Press/Politics 8:27-48. doi: $10.1177 / 1081180 \mathrm{X} 02238783$

Stephenson RL, Hobday AJ, Cvitanovic C, Alexander KA, Begg GA, Bustamante R, Dunstant PK, Frusher S, Fudge M, Fulton EA, Haward M, Macleod C, McDonald J, Nash KL, Ogier E, Pecl G, Plaganyi EE, van Putten I, Smith ADM, Ward TM (2019) A practical framework for implementing and evaluation integrated management of marine activities. Ocean Coast Manage 177:127-138. doi: 10.1016/j.ocecoaman.2019.04.008 
Strand JR, Tuman JP (2012) Foreign Aid and Voting Behavior in an International Organization: The Case of Japan and the International Whaling Commission. Foreign Policy Anal 8:409-430. doi: 10.1111/j.17438594.2011.00173.x

Sumaila UR, Ebrahim N, Schuhbauer A, Skerritt D, Li Y, Kim HS, Mallory TG, Lam VWL, Pauly D (2019) Updated estimates and analysis of global fisheries subsidies. Mar Policy 109:104706. doi: 10.1016/j.marpol.2019.103695

Thorson JT, Jensen OP, Hilborn R (2014) Probability of stochastic depletion: an easily interpreted diagnostic for stock assessment modelling and fisheries management. ICES J Mar Sci 72:428-435. doi: 10.1093/icesjms/fsu127

Townsend RE, Townsend R, Shotton R, Uchida H (2008) Case studies in fisheries self-governance. Food \& Agriculture Organisation, Rom

Turner RA, Addison J, Arias A, Bergseth BJ, Marshall NA, Morrison TH, Tobin RC (2016) Trust, confidence, and equity affect the legitimacy of natural resource governance. Ecol Soc 21:18. doi: 10.5751/ES-08542210318

Tyler T (1990) Why People Obey the Law. Yale University Press, New Haven CT

Uğurlu Ö, Yildirim Ö, Başar E (2015) Analysis of grounding accidents caused by human error. J Mar Sci Tech 23:748-760. doi: 10.6119/JMST-015-0615-1

Underdal A (1980) The politics of international fisheries management. The case of the Northeast Atlantic. Universitetsforlaget, Oslo, Norway

Underdal A (2002) One question, two answers. In: Miles EL, Underdal A, Andresen S, Wttestad J, Skjærseth JB, Carlin EM (ed) Environmental regime effectiveness: Confronting theory with evidence. MIT Press, Cambridge, Massachusetts, pp: 3-45

United Nations (1995) Agreement for the Implementation of the Provisions of the United Nations Convention on the Law of the Sea of 10 December 1982 Relating to the Conservation and Management of Straddling Fish Stocks and Highly Migratory Fish Stocks. https://documents-ddsny.un.org/doc/UNDOC/GEN/N95/274/67/PDF/N9527467.pdf?OpenElement. Accessed 26 February 2020

United Nations Treaty Collection (2020) Law of the Sea. https://treaties.un.org/Pages/ViewDetails.aspx?src=TREATY\&mtd no $=$ XXI-7\&chapter $=21 \&$ clang $=$ _en. Accessed 21 July 2020

Vandeweerd V, Cicin-Sain B, Balgos MC, Williams LC, Bernal P (2006) Meeting the Commitments on Oceans, Coasts, and Small Island Developing States Made at the 2002 World Summit on Sustainable Development: How Well Are We Doing?. Global Forum on Oceans, Coasts, and Islands, UNESCO, Paris

Vince J (2015) Integrated policy approaches and policy failure: the case of Australia's Oceans Policy. Policy Sci 48:159-180. doi: 10.1007/s11077-015-9215-Z

Vince J, Brierley E, Stevenson S, Dunstan P (2017) Ocean governance in the South Pacific region: Progress and plans for action. Mar Policy 79:40-45. doi: 10.1016/j.marpol.2017.02.007

Vince J, Hardesty BD (2018) Governance Solutions to the Tragedy of the Commons That

Marine Plastics Have Become. Front Mar Sci 5:214. doi: 10.3389/fmars.2018.00214.

Vince J, Haward M (2019) Hybrid governance in aquaculture: Certification schemes and third party accreditation. Aquaculture 507:322-328. doi: 10.1016/j.aquaculture.2019.04.041

Voyer M, Quirk G, McIlgorm A, Azmi K (2018) Shades of blue: what do competing interpretations of the Blue Economy mean for oceans governance. J Environ Policy Plan 20:595-616. doi: 10.1080/1523908X.2018.1473153 
Weeks R, Jupiter SD (2013) Adaptive co-management of a marine protected area network in Fiji. Conserv Biol 27:1234-1244. doi: 10.1111/cobi.12153

Weiss K, Hamann M, Kinney M, Marsh H (2012) Knowledge exchange and policy influence in a marine resource governance network. Global Environ Chang 22:178-188. doi: 10.1016/j.gloenvcha.2011.09.007

Weiss K, Hamann M, Marsh H (2013) Bridging Knowledges: Understanding and Applying Indigenous and Western Scientific Knowledge for Marine Wildlife Management. Soc Nat Resour 26:285-302: doi: $10.1080 / 08941920.2012 .690065$

Williamson DH, Evans RD, Russ GR (2006) Monitoring the Ecological Effects of Management Zoning: Initial Surveys of Reef Fish and Benthic Communities on Reefs in the Townsville and Cairns Regions of the Great Barrier Reef Marine Parks. A Report to the Great Barrier Reef Marine Park Authority

Willock A, Lack M (2006). Follow the Leader: Learning from Experience and Best Practice in Regional Fisheries Management Organisations. WWF Int'n and TRAFFIC Int'n.

Young OR (1991) Political leadership and regime formation: On the development of institutions in international society. Int Org 45:281-308. doi: 10.1017/S0020818300033117

Young OR, Osherenko G, Ekstrom J, Crowder LB, Ogden J, Wilson JA, Day JC, Douvere F, Ehler CN, McLeod KL, Halpren BS, Peach R (2007) Solving the Crisis in Ocean Governance: Place-Based Management of Marine Ecosystems. Environment: Science and Policy for Sustainable Development. 49:20-32. doi:10.3200/ENVT.49.4.20-33

Young OR (2010) Institutional dynamics: Resilience, vulnerability and adaptation in environmental and resource regimes. Glob Environ Chang 20:378-385. doi: 10.1016/j.gloenvcha.2009.10.001

Zheng G (2018) Human rights for conservation: A rights-based approach to fisheries governance. Alt L J 43:55-59. doi: 10.1177/1037969X17748375 